\title{
IMPLEMENTASI MODEL DAN DESAIN PEMBELAJARAN DARING PADA ANAK USIA DINI SAAT PANDEMI COVID 19 DI TK PERWANIDA SOOKO PONOROGO
}

\author{
Zamzam Mustofa \\ Institut Agama Islam Negeri Ponorogo \\ Email: zamzam@iainponorogo.ac.id \\ Dica Nurul Azizah \\ Institut Agama Islam Negeri Ponorogo \\ Email : dicanurul15@gmail.com \\ Ruaidatul Fitriyah \\ Institut Agama Islam Negeri Ponorogo \\ Email: fitridhatul302@gmail.com
}

\begin{abstract}
Early Childhood Education is education at an early stage, in early childhood, children learn from those who cannot until they can. Of course, to teach children, teachers who are able to educate children well. As a good educator, he must have a learning model or design to support the teacher when teaching children. With this the purpose of this research is written to find out how to model and design good learning for children. Moreover, during a pandemic like this, the teacher must choose the appropriate and suitable learning model and design for children while studying at home. By using descriptive methods we can find out how an educator applies models and designs for early childhood. This research results that learning models and designs are very important for early childhood. learning models and designs such as role models or guidelines used by educators when carrying out learning activities for early childhood at school. If educators do not have a learning model or design that is suitable for early childhood, the teachers / educators will be confused about what kind of learning is appropriate and suitable for early childhood. As well as learning models and designs that are appropriate to use during a pandemic like this is to create a sense of comfort and safety even though they continue to carry out learning activities at home. Teachers / educators must prepare effective and efficient work programs so that they can improve the skills and intelligence of their students when studying at home.
\end{abstract}

\section{Keywords: Early Childhood Education, Learning Models and Designs}

\footnotetext{
Abstrak: Pendidikan Anak Usia Dini adalah pendidikan pada tahap awal, di PAUD anak belajar mulai dari yang tidak bisa hingga bisa. Tentunya untuk mengajarkan anak perlu guru-guru yang mampu mendidik anak dengan baik. Sebagai pendidik yang baik haruslah memiliki model atau desain pembelajaran agar menunjang guru saat mengajar anak-anak. Dengan ini tujuan penelitian ini ditulis adalah mengetahui bagaimana model dan desain pembalajaran yang baik bagi anak-anak. Terlebih lagi disaat pandemi seperti ini guru harus memilih model dan desain pembelajaran yang tepat dan cocok untuk anakanak saat belajar dirumah masing-masing. Dengan menggunakan metode desktiptif kita dapat mengetahui bagaimana seorang pendidik menerapkan model dan desain untuk anak usia dini. Penelitian ini menghasilkan bahwa model dan desain pembelajaran sangatlah penting bagi anak usia dini. model dan desain pembelajaran seperti panutan atau pedoman yang digunakan pendidik saat melakukan kegiatan pembelajaran terhadap
} 
Zamzam Mustofa dkk, Implementasi Model dan Desain Pembelajaran Daring pada Anak Usia Dini saat Pandemi Covid 19

anak usia dini di sekolah. Jika pendidik tidak memiliki model atau desain pembelajaran yang pas untuk anak usia dini, maka para guru/pendidik akan kebingungan menentukan pembelajaran seperti apa yang tepat dan cocok digunakan untuk anak usia dini. Serta model dan desain pembelajaran yang tepat digunakaan saat pandemi seperti ini adalah menciptakan rasa nyaman dan aman meskipun tetap menjalankan kegiatan belajar dirumah. Guru/pendidik harus mempersiapkan program kerja yang efektif dan efisien sehingga dapat meningkatkan keterampilan dan kecerdasan muridnya saat belajar dirumah.

Kata Kunci: Pendidikan Anak Usia Dini, Model dan Desain Pembelajaran Daring, Pandemi

\section{PENDAHULUAN}

Anak merupakan ciptaan tuhan berwujud manusia kecil yang memiliki sebuah potensi yang sudah seharusnya dikembangkan. Anak mempunyai karakteristik khusus dan tentu saja mempunyai ciri khas yang berbeda dengan yang dimiliki oleh orang dewasa. Ciri tersebut yaitu aktif, dinamis, antusias serta mempunyai rasa ingin tahu tentang sesuatu yang dilihatnya, didengar, dirasakan, anak akan merasa seolah-olah mereka tak bisa berhenti untuk mengeksplorasi sesuatu serta belajar. ${ }^{1}$ Untuk kehidupan manusia, pendidikan sangatlah penting apalagi untuk anakanak, pemerintah setempat juga harus ikut andil dalam proses pendidikan, agar tujuan pendidikan yang sudah dibuat bisa terlaksana dengan baik dan lancar. $^{2}$ Lembaga atau sekolah yang berada dibawah naungan pemerintah akan melaksanakan kebijakan yang telah diatur. Pendidikan merupakan gambaran dari kondisi masyarakat. Tujuan dari pendidikan dapat terwujud jika pendidikan itu sendiri dapat memberi manfaat bagi kehiduapan masyarakat.

Pembelajaran pada Anak Usia Dini adalah salah satu terciptanya proses yang melibatkan anak, orang tua, serta orang dewasa lainnya yang terdapat di lingkungan sekitarnya. Interaksi yang terjadi pada anak, orang

${ }^{1}$ La Hewi and others, 'Jurnal Obsesi : Jurnal Pendidikan Anak Usia Dini Strategi Pendidik Anak Usia Dini Era Covid-19 Dalam Menumbuhkan Kemampuan Berfikir Logis', Jurnal $\begin{array}{lllll}\text { Pendidikan Anak Usia Dini, } 5.1 & \text { (2021), } & 158-67\end{array}$ $<$ https://doi.org/10.31004/obsesi.v5i1.530>.

${ }^{2}$ Hijiriati Dosen Fakultas Tarbiyah dan Keguruan UIN Ar-Raniry Banda Aceh, PENGEMBANGAN MODEL PEMBELAJARAN PENDIDIKAN ANAK USIA DINI, 2017. 
tua, dan orang dewasa merupakan salah satu faktor tercapainya tujuan dari suatu proses pembelajaran. Dengan adanya interaksi anak akan memperoleh sebuah pengalaman yang akan berguna untuk dirinya sehingga anak dapat melaksanakan proses pembelajaran dengan baik dan maksimal.

Pembelajaran anak usia dini bukan hanya harus belajar di dalam kelas saja ataupun di sekolah. Namun, terdapat orang tua yang memaksa anaknya agar masuk sekolah pada umur tertentu dan akhirnya justru membuat anak menjadi terbebani dalam mencapai perkembangannya. Suatu pembelajaran yang dapat meningkatkan perkembangan anak adalah dengan bermain, bermain justru malah dapat membuat anak merasa gembira, senang, karena dapat memilah dan memilih permainan serta karakteristik seperti apa yang dimiliki oleh anak. Pembelajaran pada Anak Usia Dini harus dirancang dengan baik agar saat proses pembelajaran anak merasa nyaman dan tidak terbebani. Setiap anak memiliki pengalaman yang mereka ambil dari proses pembelajaran yang telah mereka lalui, anak juga memiliki pengetahuan yang telah mereka punya untuk mendapat pengalaman-pengalaman yang baru.

Pada saat ini semua aktivitas atau kegiatan yang kita laksanakan termasuk di bidang pendidikan, semua tidak berjalan dengan lancar karena pandemi COVID-19. Terlebih lagi kegiatan proses pembelajaran melibatkan banyak orang, sehingga kegiatan pembelajaran yang awalnya dilaksanakan secara langsung atau tatap muka, sekarang diganti dengan pembelajaran jarak jauh (Daring) menggunakan teknologi yang ada pada saat ini dikarenakan seluruh masyarakat harus menjaga jarak (social distancing). Bukan hanya untuk anak usia dini saja, tetapi semua jenjang pendidikan juga menerapkan hal ini mulai dari perguruan tinggi, SMA, SMP, dan SD. 
Zamzam Mustofa dkk, Implementasi Model dan Desain Pembelajaran Daring pada Anak Usia Dini saat Pandemi Covid 19

\section{METODE PENELITIAN}

Metode penelitian merupakan langkah yang dimiliki dan dilakukan oleh peneliti untuk mengumpulkan informasi atau data serta melakukan investigasi pada data yang telah didapatkan. ${ }^{3}$ Metode yang akan digunakan oleh peneliti adalah metode penelitian deskriptif yang mana peneliti mensurvei suatu kasus yang ada serta menganalisis kasus tersebut. Metode deskriptif adalah suatu cara untuk memecahkan masalah dalam penelitian suatu objek untuk mengenali beberapa kebenaran yang perlu diselidiki dari suatu kelompok masyarakat. ${ }^{4}$ Alasan digunakan metode deskriptif dalam penelitian ini adalah penelitian dapat berjalan dengan lancar dan peneliti memperoleh gambaran yang sesui mengenai implementasi model dan desain pembelajaran anak usia dini di TK Perwanida Sooko Ponorogo. Penelitian ini berasal dari sumber data yang dikumpulkan dengan metode dekriptif. Maka tujuan dari penelitian deskripsi adalah untuk membuat gambaran tentang keadaan serta lukisan secara sistematis, faktual dan akurat mengenai fakta-fakta kebenaran, sifat-sifat serta hubungan antar suatu fenomena yang akan diselidiki. ${ }^{5}$

Dalam penelitian ini lebih menekankan pada kekuatan analisis sumber dan data yang ada untuk kemudian dianalisis berdasarkan data yang sudah didapatkan. Sumber tersebut didapatkan dari:

1. Guru-guru TK Perwanida Sooko Ponorogo

2. Murid-murid TK Perwanida Sooko Ponorogo

3. Orang Tua/Wali Murid TK Perwanida Sooko Ponorogo

\footnotetext{
${ }^{3}$ METODE PENELITIAN: Pengertian, Tujuan, Jenis - Uji Statistik<Https://Www.Statistikian.Com/2017/02/Metode-Penelitian-Metodologi-

Penelitian. Html> [Accessed 2 October 2020].

${ }^{4}$ La Hewi And Others, Jurnal Obsesi : Jurnal Pendidikan Anak Usia Dini Strategi Pendidik Anak Usia Dini Era Covid-19 Dalam Menumbuhkan Kemampuan Berfikir Logis, Jurnal $\begin{array}{lllll}\text { Pendidikan Anak Usia Dini, } & 5.1 & \text { (2021), } & \text { 158-67 }\end{array}$ $<$ Https://Doi.Org/10.31004/Obsesi.V5i1.530>.

5 I Made Tegeh And I Made Kirna, Pengembangan Bahan Ajar Metode Penelitian Pendidikan Dengan Addie Model, Jurnal IKA, 11.1 (2013) $<$ Https://Ejournal.Undiksha.Ac.Id/Index.Php/IKA/Article/View/1145> [Accessed 2 October 2020].
} 
Selanjutnya teknik pengumpulan data, teknik pengumpulan data adalah langkah-langkah yang sistematis dan biasa dilakukan dalam memperoleh data yang diperlukan. Teknik pengumpulan data yang dilakukan peneliti ini adalah dengan metode wawancara. Metode ini dilakukan melalui kegiatan dengan subjek untuk mengumpulkan informasi dengan cara berkomunikasi secara langsung. Agar wawancara dapat mengumpulkan data berkualitas baik, maka peneliti harus memiliki pertanyaan yang baik. Peneliti memilih teknik pengumpulan data ini karena informasi yang akan didapatkan sangat luas dan mudah dipahami, sehingga membantu peneliti mendapatkan hasil penelitian yang baik dan memuaskan.

Dari data yang berhasil didapatkan maka dilakukan proses analisis, berikut adalah teknik analisis data yang digunakan peneliti.

1. Triangulasi adalah teknik pemeriksaan kebenaran data yang memanfaatkan untuk memeriksa sesuatu yang lain di luar data yang berada dalam penelitian sebagai pembanding terhadap data tersebut. Terdapat tiga macam triangulasi yaitu triangulasi dengan sumber penelitian, triangulasi dengan teknik penelitian, dan triangulasi waktu penelitian. Penelitian ini, penulis menggunakan teknik triangulasi dengan cara wawancara langsung agar mendapatkan data yang sesuai dengan tema dan diperoleh dari narasumber di TK Perwanida Sooko Ponorogo.

2. Reduksi data adalah bentuk analisis yang dapat mempertajam, menggolongkan, mengarahkan, menyaring yang tidak perlu, dan mengelompokkan data sedemikian rupa sehingga kesimpulan dapat ditemukan. Reduksi data disebut sebagai kuantifikasi data. ${ }^{6}$ Dalam penelitian ini, penulis mengumpulkan data-data terkait

${ }^{6}$ Rahmi Susilawati and others, Analisis Pengembangan Bakat Khusus Pada Siswa Kelas $X$ Madrasah Aliyah Negeri 2 Pontianak. 
Zamzam Mustofa dkk, Implementasi Model dan Desain Pembelajaran Daring pada Anak Usia Dini saat Pandemi Covid 19

model dan desain pembelajaran anak usia dini didapat dari hasil wawancara bersama guru-guru di TK Perwanida Sooko Ponorogo.

3. Penyajian data yaitu kegiatan ketika sekumpulan data atau informasi disusun, sehingga memberi kemungkinan adanya penarikan kesimpulan. Bentuk penyajian data ini berupa teks naratif (berbentuk catatan lapangan), matriks, grafik, dll. Peneliti mengumpulkan data yang telah didapat saat proses wawancara dan di tulis sedemikian rupa, sehingga nanti dapat ditarik kesimpulan.

4. Penarikan kesimpulan yaitu hasil analisis yang dapat digunakan untuk mengambil tindakan. Peneliti melakukan penarikan kesimpulan dari data atau informasi yang telah didapat dari proses wawancara dengan guru TK Perwanida Sooko Ponorogo dan telah disajikan.

Berdasarkan beberapa keterangan diatas, dapat disimpulkan bahwa dengan menggunakan metode penelitian tersebut, akan dikumpulkan hasil yang relevan dengan permasalahan yang ada. Hasil dari metode penelitian ini diharapkan dapat menjawab persoalan yang ada dalam semua permasalahan dengan jelas dan tepat.

\section{KERANGKA TEORI}

\section{A. Hakikat Anak Usia Dini}

Usia dini adalah suatu periode awal yang paling penting dan mendasar pada pertumbuhan serta perkembangan kehidupan manusia. ${ }^{7}$ Masa ini dapat ditandai dengan berbagai periode penting dalam kehidupan anak selanjutnya sampai periode akhir pertumbuhan dan perkembangannya. Salah satu periode yang menjadi ciri penting masa usia dini adalah periode keemasan. Banyak konsep dan tentunya fakta

\footnotetext{
7 Dadan Suryana and M Pd, Hakikat Anak Usia Dini.Padang: UNP Press Padang
} 
yang dapat ditemukan memberikan penjelasan periode keemasan pada masa usia dini, yaitu masa semua potensi anak berkembang paling cepat.

Ki Hajar Dewantara merangkumkan semua potensi yang dimiliki anak menjadi cipta, rasa, dan karsa. Teori Multiple Intelligencies (kecedasaran ganda) dan Garner menyatakan bahwa kecerdasan ganda memiliki delapan tipe kecerdasan. ${ }^{8}$ Biasanya seorang anak memiliki satu atau lebih dari kedelapan kecerdasan tersebut, tetapi juga amat jarang yang memiliki kecerdasan secara sempurna. Pada masa ini pertumbuhan otak anak sedang mengalami perkembangan yang sangat pesat (eksploratif), begitu juga dengan perkembangan fisiknya. Pertumbuhan dan perkembangan tersebut telah dimulai sejak prenatall atau sejak dalam kandungan. Pembentukan sel syaraf otak ini merupakan modal pembentukkan kecerdasan, yang akan terjadinya saat anak dalam kandungan, dan setelah lahir tidak akan terjadi lagi pembentukkan sel saraf otak, tetapi antar sel saraf otak terus berkembang.

Konsep-konsep yang merupakan pembentuk masa suatu anak berusia dini adalah masa eksplorasi, masa identifikasi/imitasi, masa peka, masa bermain, dan masa membangkang tahap awal. Namun, di sisi lain anak usia dini berada pada masa kritis, yaitu masa keemasan. Anak tidak akan dapat mengulang masa keemasan ini kembali pada masa-masa berikutnya apabila potensi-potensinya tidak distimulasi secara optimal dan maksimal pada usia dini tersebut. Dampak dari keemasan yang tidak distimulasi dengan benar dapat menimbulkan hambatan tahap perkembangan anak berikutnya. Jadi, usia emas suatu anak hanya dapat dialami sekali dan tidak dapat diulang kembali.

${ }^{8}$ Desain Pengembangan Pembelajaran Tematik, Bagi Anak Usia Dini - Google Play $<$ https://play.google.com/books/reader?id=LFFADwAAQBAJ\&hl=id\&pg=GBS.PR10> [accessed 10 October 2020]. 
Zamzam Mustofa dkk, Implementasi Model dan Desain Pembelajaran Daring pada Anak Usia Dini saat Pandemi Covid 19

\section{B. Model Desain Pembelajaran Anak Usia Dini}

Berdasarkan perkembangan teori dari Piaget, masa anak usia dini merupakan masa yang pendek tetapi merupakan masa yang sangat penting bagi kehidupan seseorang. Karakteristik perkembangan TK/RA biasanya pertumbuhan fisiknya mencapai kematangan mereka dengan mampu mengontrol tubuh dan keseimbanganya. Selanjutnya pada perkembangan sosialnya anak telah ditunjukkan kepribadiannya tentang pengetahuan jenis kelaminnya, telah mampu melaksanakan kompetensi dengan teman sebayanya, mampu bersahabat dengan baik (teman dekat) dan telah mampu berbagi dan mandiri. Pada perkembangan emosi, anak sudah dapat mengekspresikan reaksi terhadap orang lain, dapat mengontrol emosinya, sudah mampu berpisah dengan orang tua tidak bergantung pada orang tua saja dan telah mulai belajar antara hal yang benar dan salah.

Menurut Piaget, setiap anak memiliki cara tersendiri dalam menginterpretasikan dan beradaptasi dengan lingkungannya (teori perkembangan kognitif). Banyak sekali metode yang dapat dikembangakan dan diterapkan di TK/RA. Hal yang terpenting dalam mengembangkan model pembelajaran bagi PAUD harus memperhatikan karakteristik anak dan kompetensi yang akan dicapai, interaksi dalam proses pembelajaran, alat/media, dan penilaian. Tetapi tetap dengan berdasarkan sifat dan karakter anak usia dini, maka pembelajaran di TK/RA bersifat tematik yang dilakukan secara integratif, artinya bahwa pembelajaran tidak dilakukan dengan metode tunggal bersifat paduan (integral).

Desain pembelajaran hakikatnya merupakan pengembangan pembelajaran secara sistematis menggunakan teori-teori pembelajaran untuk menjamin kualitas suatu pembelajaran menurut Sagala. Lebih detail Joyoatmodjo mengartikan desain pembelajaran sebagai upaya pengembangan secara sistematis antar komponen pembelajaran dengan 
menggunakan teori belajar tertentu. ${ }^{9}$ Dengan demikian dapat diketahui bahwa desain pembelajaran merupakan upaya untuk mengembangkan pembelajaran secara sistematis berdasarkan teori belajar dan pembelajaran sehingga dapat menjamin kualitas pendidikan, maka istilah model desain pembelajaran dapat dipahami sebagai konkretisasi teori pengembangan pembelajaran secara sistematis dengan menggunakan teori pembelajaran tertentu untuk menjamin kualitas pembelajaran yang berisi prinsip-prinsip, konstruk, tujuan dan langkah- langkah.

C. Implementasi Model dan Desain Pada Anak Usia Dini

Pengajaran adalah suatu pembelajaran yang lebih menyangkut kepada aspek pengetahuan dan keterampilan yang bermanfaat bagi kehidupannnya kelak. Sedang pendidikan lebih menyangkut aspek kepribadian. Kegiatan pengajaran yang dimaksud adalah untuk menumbuhkembangkan potensi yang dimiliki oleh peserta didik terkait dengan potensi pikir (intelektual) dan potensi raga (kinestetik). Pada kegiatan pendidikan ditekankan untuk menumbuhkan dan mengembangkan potensi peserta didik yang terkait pada potensi rasa, karsa dan religi (kecerdasan sosial, semangat jiwa, serta keimanan dan ketakwaan). Keseimbangan antara aspek pengajaran dan pendidikan harus disesuaikan dengan setiap level/jenjang pendidikan.

Pada jenjang pendidikan level bawah seperti pendidikan anak usia dini (PAUD), kebutuhan aspek pendidikan harus lebih banyak dari pada aspek pengajaran. Sebaliknya untuk jenjang pendidikan tinggi, kebutuhan pada aspek pengajaran harus lebih banyak dari pada aspek pendidikan. Pelaksanaan pembelajaran tidak terlepas dari komponen yang harus

9 Annisa Tiara Widya Saputri and PGSD FKIP Universitas Kristen Satya Wacana, Pengembangan Desain Pembelajaran Tematik Integratif Berbasis Pendekatan Contextual Teaching And Learning (Ctl) Kelas 4 Sekolah Dasar, Jurnal IImiah "Pendidikan Dasar, $2017 \quad$ <http://lppmunissula.com/jurnal.unissula.ac.id/index.php/pendas/article/view/2735> [accessed 10 October 2020]. 
Zamzam Mustofa dkk, Implementasi Model dan Desain Pembelajaran Daring pada Anak Usia Dini saat Pandemi Covid 19

dikembangkan guru yaitu metode dan media pembelajaran. ${ }^{10}$ Guru diharuskan untuk mampu mengembangkan model pembelajaran terutama pada anak usia dini yang dapat memberikan pengalaman belajar pada siswanya, sehingga mereka dapat mengembangkan potensinya secara optimal.

D. Implementasi Model dan Desain Pembelajaran Daring pada Anak Usia Dini Saat Pandemi Covid-19 di TK Perwanida Sooko Ponorogo

Pada masa pademi covid ini tentunya membuat anak-anak merasa sangat tidak nyaman karena sering dirumah saja, tanpa bisa belajar dan melakukan pembelajaran di kelas. Orang tua juga seharusnya dapat memberitahu tentang hal yang positif dan perkataan yang positif agar anak tetap merasa aman walau dirumah saja. Tentu saja untuk para pendidik seperti guru TK lebih mempelajari dan memikirkan hal yang lebih efektif dan efisien bagi pembelajaran anak usia dini agar tetap bisa berjalan dengan lancar.

Model Pengembangan Plomp memiliki 3 fase yang digunakan pada saat menerapkan Desain Pembelajaran, yaitu 1. Penelitian Awal, 2. Fase Prototype, 3. Fase Penilaian. Pada fase pertama yaitu fase penelititian awal, dimana fase ini adalah fase dimana kita mengamati kondisi yang ada, jalannya pembelajaran khususnya pada saat Pandemi COVID-19 sekarang ini. Pada tahap ini peneliti melakukan penelitian yang digunakan untuk mengidentifikasi apa saja kebutuhan yang dibutuhkan untuk mengembangkan RPP walaupun dilakukan/dilakukan dirumah.

Fase yang kedua yaitu fase prototype, dimana fase ini adalah merancang/membuat RPP yang selanjutnya akan diteliti oleh peneliti. Dalam RPP ini akan dikembangkan beberapa komponen, terdiri dari

\footnotetext{
10 Implementasi Model Pembelajaran Pdf - Penelusuran Google $<$ https://www.google.com/search?safe=strict\&sxsrf=ALeKk03_vweMCJdhnyyJJNi8mVzh aFEzJg\%3A1602319036113\&ei=vHKBX4S5BpqGyAPLkIABg\&q=implementasi+model+p embelajaran+pdf\&oq=implementasi+model+pembelajaran+pdf\&gs_lcp=CgZwc3ktYWIQA zIECAAQHjoECAAQRzoECCEQCjoFCAAQzQJQ0bADWKujBGCmsQRoAHACeACAAb kJiAHPmQGSAQg1LTEwLjcuN5gBAKABAaoBB2d3cy13aXrIAQjAAQE\&sclient=psyab\&v ed=0ahUKEwiEh9vHz6nsAhUaA3IKHUvIA2AQ4dUDCAw\&uact=5> [accessed 10 October 2020].
} 
komponen utama, seperti identitas mata pelajaran, nama mata pelajaran, kelas dan semseter, pertemuan, dan alokasi waktu. Selanjutnya Kompetensi Inti (KI), dan Kompetensi Dasar (KD) yang didalamnya menerapkan konsep aritmetika sosial, Indikator pencapaian hasil belajar, Tujuan pembelajaran, komponen-komponen pendekatan kontekstual, Materi, Sumber/Media pembelajaran, Penilaian Pembelajaran. Meskipun dalam keaadaan pandemi seperti ini guru dapat melakukan pembelajaran dan merancang RPP yang telah disusun dalam Fase Pengembangan (Prototyping Phase). Pada saat ini sudah banyak teknologi yang dapat digunakan untuk melakukan kegiatan pembelajaran dan penilaian pada siswa walaupun dirumah saja, contohnya seperti Group Whatsapp bisa menggunakan Whatsapp orang tua atau jika anak yang sudah mempunyai HP bisa menggunakan Whatsaap mereka sendiri tapi tetap dengan pengawasan orang tua, yang kemudian guru akan menilai anak dari media tersebut yang dilanjutkan ke Fase Penilaian ( Prototyping Phase).

\section{PEMBAHASAN}

Bagi sebagian orang pendidikan itu sangatlah penting, tapi ada juga yang menganggap bahwa pendidikan itu tidak penting, khususnya masyarakat yang tempat tinggalnya di pedesaan ataupun daerah yang tidak terjangkau. Tapi tidak dengan masyarakat yang berada di daerah Sooko Ponorogo, masyarakat disana mementingkan pendidikan anakanak mereka. Bisa dilihat dengan adanya TK Perwanida yang berarti masyarakat disana mendukung penuh pendidikan anaknya, terlebih pendidikan anak usia dini. Sebagian masyarakat Sooko Ponorogo ada yang memang memberikan pendidikan yang penuh sampai perguruan tinggi ada juga yang mengikuti kemauan anaknya jika ingin melanjutkan pendidikan dipersilakan, jika tidak para orang tua tidak memaksa semua keputusan diserahkan ke anaknya masing-masing. ${ }^{11}$

\footnotetext{
11'Pentingnya Pendidikan Bagi Semua Orang - Kompasiana.Com' $<$ https://www.kompasiana.com/faica18/564af5b7747e617f0885f68c/pentingnyapendidikan-bagi-semua-orang> [accessed 25 October 2020].
} 
Zamzam Mustofa dkk, Implementasi Model dan Desain Pembelajaran Daring pada Anak Usia Dini saat Pandemi Covid 19

Pendidikan bagi anak usia dini sangatlah penting, karena pada saat di pendidikan anak usia dini anak akan pembentuk mental dan karakter mereka dari kecil (usia 0-5 tahun) sebelum memasuki jenjang pendidikan sekolah dasar. Ketika anak tersebut dibentuk secara bertahap dari pendidikan sebelum sekolah selain TK, maka secara berurutan dan kedepan nanti anak tersebut akan mempunyai kreatifitas, keterampilan, dan kemampuan yang baik ketika berada pada pendidikan sekolah dasar sampai pendidikan perguruan tinggi. Hal ini sangat menolong anak-anak untuk tumbuh serta berkembangnya dengan baik. ${ }^{12}$

Model pembelajaran merupakan prosedur yang sistemasi serta dalam mengorganisasikan pengalaman belajar anak agar mencapai tujuan belajar. Dalam proses pembelajaran model pembelajaran dapat berupa pola atau gambaran besar yang dapat menjelaskan tentang bentuk,. Model pembelajaran untuk anak usia dini bisa di artikan sebagai pola, bentuk, kegiatan ataupun kerangka yang menggambarkan prosedur yang sistematis dalam mengorganisasikan pengalaman belajar anak. ${ }^{13}$

Model pembelajaran sangat berpengaruh terhadap proses belajar mengajar. Karna dengan menggunakan model pembelajaran dapat melihat atau mengamati kondisi anak, sehingga pengajar dapat menyiapkan materi sesuai dengan kondisi yang terjadi pada anak-anak tersebut sehingga akan lebih menarik dan tidak membosankan bagi anak, karna sesuai dengan kondisi mereka. Model pembelajaran telah banyak dikembangkan yang dibuktikan dengan beberapa penelitian. Model pembelajaran memiliki tujuan yaitu dapat menumbuhkan atau meningkatkan kerjasama antar anak, terciptanya rasa percaya diri pada anak.

\footnotetext{
12 'Mengapa Pendidikan Anak Usia Dini Sangat Penting? - Kompasiana.Com'. 13'MODEL PEMBELAJARAN AUD I Failashofagmail' $<$ https://failashofagmail.wordpress.com/2011/06/08/model-pembelajaran-aud/> [accessed 25 October 2020].
} 
Seorang guru harus menyiapkan atau menyusun rencana untuk pelaksanaan pembelajaran yang akan dijadikan materi dan disampaikan ke anak saat proses belajar berlangsung. Pembelajaran PAUD haruslah disesuaikan dengan karakteristik anak agar pada saat proses pembelajaran anak tidak merasa bosan. Dan seorang pengajar harus memiliki desain pembelajaran yang tujuannya membuat anak termotivasi.

Desain pembelajaran adalah praktik penyusunan media teknologi komuikasi dan isi untuk membantu agar dapat terjadi transfer pengetahuan secara efektif antara guru dan peserta didik.. ${ }^{14}$ Desain pembelajaran pada anak haruslah menciptakan rasa nyaman, aman, lingkungan bersih, dan juga menarik. Lingkungan yang seperti itu akan membuat anak lebih mudah atau dapat memahami pembelajaran yang diberikan oleh guru, karena lingkungan sangat mempengaruhi proses belajar anak dan motivasi anak saat proses pembelajaran. Dalam proses pembelajaran PAUD bisa dilakukan sambil bermain, karna pada usia tersebut anak berada dimasa bermain dan bersenang-senang, tetapi diselingi dengan pembelajaran didalamnya. ${ }^{15}$

Desain pembelajaran anak usia dini haruslah dilakukan dengan asyik, menyenangkan dan tentunya bebas tanpa ada tekanan dari siapapun. Pembelajaran tersebut dapat dilakukan dengan pengawasan orangtua, seperti melatih anak merangkai balok menjadi menara atau bisa juga menggunakan lego yang dapat dibuat menjadi bermacam-macam bentuk. Dengan demikian meskipun anak melakukan pembelajaran di rumah tidak perlu didampingi oleh guru pendidik langsung, hanya perlu didampingi oleh orangtua masing-masing.

\footnotetext{
14 'Desain Pembelajaran - Wikipedia Bahasa Indonesia, Ensiklopedia Bebas' $<$ https://id.wikipedia.org/wiki/Desain_pembelajaran> [accessed 25 October 2020].

15 'Desain Pembelajaran Pada Anak Usia Dini - Kompasiana.Com' $<$ https://www.kompasiana.com/mashnaalhumairo/54f73fd4a33311f0128b462c/desainpembelajaran-pada-anak-usia-dini> [accessed 25 October 2020].
} 
Zamzam Mustofa dkk, Implementasi Model dan Desain Pembelajaran Daring pada Anak Usia Dini saat Pandemi Covid 19

Model dan desain pembelajaran yang seharusnya dilakukan pada masa pandemi seperti sekarang adalah menciptakan pembelajaran yang aman dan nyaman meskipun pembelajaran tersebut dilakukan dirumah. Guru atau pendidik mempersiapkan program kerja yang efektif dan efisien sehingga dapat meningkatkan keterampilan dan kecerdasan peserta didiknya. Model pembelajaran yang dapat diberikan kepada anak yaitu memberi tugas menggunakan media internet yang dimiliki oleh masingmasing orang tua. Contohnya melihat cerita-cerita anak yang dapat mendidik anak tersebut, dengan melihat cerita tersebut diharapkan anak dapat mencontoh hal-hal yang positif dari cerita tersebut. Orang tua pada masa pandemi seperti sekarang ini dituntut menjadi guru bagi anak-anak mereka dirumah.

\section{KESIMPULAN}

Model dan Desain Pembelajaran sangatlah penting terlebih lagi untuk anak usia dini. model dan desain pembelajaran seperti panutan atau pedoman untuk guru saat melakukan pembelajaran terhadap anak usia dini. jika tidak memiliki model dan desain pembelejaran diawal anak guru akan kebingunan menentukan pembelajaran seperti apa yang cocok digunakan untuk anak usia dini.

Model dan desain pembelajaran yang sepatutnya dicontoh pada masa pandemi seperti ini adalah menciptakan rasa nyaman dan aman meskipun tetap menjalankan kegiatan belajar mengajar dari rumah. Guru atau pendidik mempersiapkan program kerja yang efektif dan efisien sehingga dapat meningkatkan keterampilan dan kecerdasan muridnya. Dalam model pembelajaran yang bisa dilakukan adalah memberi tugas dari media internet yang dimiliki oleh orang tua, semisal untuk melihat cerita yang dapat mendidik anak dari cerita Si Kancil. Sebagai orang tua pada masa pandemi ini diharuskan menjadi guru yang baik bagi anaknya. 
Desain Pembelajaran anak usia dini perlu dilakukan dengan rasa yang asyik, menyenangkan dan tentunya bebas tanpa ada tekanan dari siapapun. Pembelajaran tersebut dapat dijalankan dengan pengawasan orangtua sendiri seperti melatih anaknya merangkai balok-balok dijadikan menara atau berasal dari lego yang dapat dibuat bermacam-macam bentuk, dengan demikian pembelajaran meskipun tidak didampingi dengan guru pendidik yang ada disekolah langsung juga dapat membuat anak dapat belajar dirumah dengan orangtuanya.

\section{DAFTAR PUSTAKA}

Akbar,Eliyyil, 'Metode Belajar Anak Usia Dini - Google Buku' <https://books.google.co.id/books?id=MYP1DwAAQBAJ\&pg=PA14\&

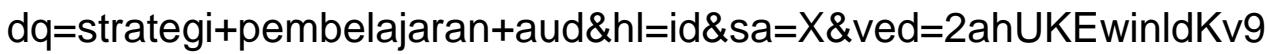
P3rAhX88HMBHRcUDnYQ6AEwBHoECAMQAg\#v=onepage\&q=str ategi pembelajaran aud\&f=false $>$ [accessed 23 September 2020].

'Desain Pembelajaran - Wikipedia Bahasa Indonesia, Ensiklopedia Bebas' <https://id.wikipedia.org/wiki/Desain_pembelajaran> [accessed 25 October 2020].

'Desain Pembelajaran Pada Anak Usia Dini - Kompasiana.Com' <https://www.kompasiana.com/mashnaalhumairo/54f73fd4a33311f0 128b462c/desain-pembelajaran-pada-anak-usia-dini> [accessed 25 October 2020].

'Desain Pengembangan Pembelajaran Tematik, Bagi Anak Usia Dini Google

Play'<https://play.google.com/books/reader?id=LFFADwAAQBAJ\&hl $=\mathrm{id} \& \mathrm{pg}=$ GBS.PR10 $>$ [accessed 10 October 2020].

Hewi, La, and others, "Jurnal Obsesi : Jurnal Pendidikan Anak Usia Dini Strategi Pendidik Anak Usia Dini Era Covid-19 Dalam Menumbuhkan Kemampuan Berfikir Logis", Jurnal Pendidikan Anak Usia Dini, 5.1 (2021). 
Zamzam Mustofa dkk, Implementasi Model dan Desain Pembelajaran Daring pada Anak Usia Dini saat Pandemi Covid 19

Hijriati Dosen Fakultas Tarbiyah dan Keguruan UIN Ar-Raniry Banda Aceh,"Pengembangan Model Pembelajaran Pendidikan Anak Usia Dini", 2017.

'Implementasi Model Pembelajaran Pdf - Penelusuran Google' <https://www.google.com/search?safe=strict\&sxsrf=ALeKk03_vweM CJdhnyyJJNi8mVzhaFEzJg\%3A1602319036113\&ei=vHKBX4S5Bp qGyAPLkIABg\&q=implementasi+model+pembelajaran+pdf\&oq=impl ementasi+model+pembelajaran+pdf\&gs_lcp=CgZwc3ktYWIQAzIEC AAQHjoECAAQRzoECCEQCjoFCAAQzQJQ0bADWKujBGCmsQRo AHACeACAAbkJiAHPmQGSAQg1LTEwLjcuN5gBAKABAaoBB2d3c y13aXrIAQjAAQE\&sclient=psyab\&ved=0ahUKEwiEh9vHz6nsAhUa A3IKHUvIA2AQ4dUDCAw\&uact=5> [accessed 10 October 2020].

'Mengapa Pendidikan Anak Usia Dini Sangat Penting? Kompasiana.Com'

<https://www.kompasiana.com/shobahbahar/54f84126a33311d45d8 b47e1/mengapa-pendidikan-anak-usia-dini-sangat-penting> [accessed 25 October 2020].

'METODE PENELITIAN: Pengertian, Tujuan, Jenis - Uji Statistik' <https://www.statistikian.com/2017/02/metode-penelitianmetodologi-penelitian.html> [accessed 2 October 2020].

'MODEL PEMBELAJARAN AUD | Failashofagmail' $<$ https://failashofagmail.wordpress.com/2011/06/08/modelpembelajaran-aud/> [accessed 25 October 2020].

'Pentingnya Pendidikan Bagi Semua Orang - Kompasiana.Com' <https://www.kompasiana.com/faica18/564af5b7747e617f0885f68c/ pentingnya-pendidikan-bagi-semua-orang> [accessed 25 October 2020].

Pramita, Mitra, Sri Mulyati, and Hery Susanto, Implementasi Desain Pembelajaran Pada Kurikulum 2013 Dengan Pendekatan Kontekstual. 
Saputri, Annisa Tiara Widya, and PGSD FKIP Universitas Kristen Satya Wacana, Pengembangan Desain Pembelajaran Tematik Integratif Berbasis Pendekatan Contextual Teaching And Learning (Ctl) Kelas 4 Sekolah Dasar, Jurnal IImiah "Pendidikan Dasar, 2017 $<$ http://lppmunissula.com/jurnal.unissula.ac.id/index.php/pendas/arti cle/view/2735> [accessed 10 October 2020].

Suryana, D. (2014). Hakikat anak usia dini. Padang: UNP Press Padang. Susilawati, Rahmi, and others, Analisis Pengembangan Bakat Khusus Pada Siswa Kelas X Madrasah Aliyah Negeri 2 Pontianak.

Tegeh, I Made, and I Made Kirna, 'Pengembangan Bahan Ajar Metode Penelitian Pendidikan Dengan Addie Model', Jurnal IKA, 11.1 (2013) <https://ejournal.undiksha.ac.id/index.php/IKA/article/view/1145> [accessed 2 October 2020]. 